\title{
Cleaning up after the Celtic Tiger: scalar 'fixes' in the political ecology of Tiger economies
}

\author{
Mark Boyle
}

This paper explores intersections between political economy and nature in the so-called Tiger economies that have risen to prominence since the 1960s. Whilst Tiger states are in many ways emblematic of the extremes of late capitalism, they are nevertheless characterized by socio-natural environments that are distinctive, both in terms of the political and economic interests that have underpinned them and their rates of production. Whilst produced under a distinctive set of capitalist social relations, the dialectical reading offered herein chooses to foreground the agency that socio-nature itself possesses in relation to prevalent class interests. This agency is conceptualized in terms of a series of cultural wars over transformed nature. Using a theoretically provocative case study that examines the politics of waste management in Ireland, the paper argues that in reflecting upon the role of such culture wars in the constitution of dominant social relations in Tiger states, the concepts of scalar strategies and struggles over scale may prove useful. Whilst social contests over the scaling of governance have tended thus far to focus upon the dialectical relations between scale and political economy, the paper argues that ecological projects too are fundamentally produced by and implicated in the structuration of scale. In calling for dialogue between political ecological studies and recent work in geography that has sought to theorize scale as a social process, the paper hopes to contribute towards the development of a political ecology of Tiger states.

key words Ireland political ecology Tiger states socio-nature culture wars waste scale

\begin{abstract}
Department of Geography, University of Strathclyde, Graham Hills Building, 50 Richmond Street, Glasgow G1 1XN

email: mark.boyle@strath.ac.uk
\end{abstract}

revised manuscript received 15 January 2002

\begin{abstract}
Since the overwhelming mass of human social metabolism with nature is now conducted through capitalist relations of production, circulation, and consumption, it is the theoretical analysis of these forms that demands the most urgent attention. (Benton 2000, 93)

The relationship between scalar structuration and other forms of socio-spatial structuration under capitalism may be explored most fruitfully through contextually specific yet theoretically self reflexive investigations. (Brenner 2001, 605)
\end{abstract}

\section{Introduction}

Concomitant with the rise to prominence of political ecology approaches within geography has been a growing interest in the excavation of the historical geography of the socio-natural environments that have marked the capitalist mode of production (Smith 1984; Castree 1995; Harvey 1996; Swyngedouw 1996 1999). Focusing upon the so-called Tiger economies that have risen to 
prominence since the 1960s, this paper is interested in exploring the intersections between political economy and nature that have characterized one particularly influential model of capitalist development. Whilst Tiger states are in many ways emblematic of the extremes of late capitalism, this paper will attempt to show that both in terms of the processes underlying, and the rates of production of, socio-nature, they are indeed unique.

Governed under a 'developmental' state model and inspired by export-oriented industrialization, Tiger states have managed to secure incredibly rapid integration into the world economy. Accompanying historically unprecedented rates of economic growth, however, has been historically unprecedented transformations of nature, transformations that have been coloured by the tendency of the Tigers to house a disproportionate number of global investments in the 'dirty industries' (Leonard 1988; Hardoy et al. 1992). The result, according to Bello and Rosenfield $(1990,12)$ has been that 'export oriented industrialisation has telescoped into three decades processes of environmental destruction that took many more years to unfold in earlier industrialising societies'.

Central to the argument advanced in this paper is the claim that emerging socio-natural environments in Tiger states have agency. Although transformed nature bears the imprint of dominant accumulation strategies, so too does it represent an ongoing threat to the social relations that have underpinned growth. Whether it be in terms of growing waste mountains in Rio de Janeiro or Dublin, urban air pollution in Seoul or Hong Kong, the eutrophication of river water in Tapei or Bangkok, or the increased acidity of rain in New Delhi and Mexico City (OECD 2001a), socionature must be seen to have been produced by, whilst simultaneously imbricated in, the contingent reproduction of prevailing capitalist social relations.

To the extent that transformed nature has agency, the response of the developmental state to ecological threats becomes of importance. How do different developmental states conceive of ecological threats? What kinds of strategies have been adopted to secure the continued legitimacy of the dominant accumulation strategy? How do the broad range of constituencies whose material position is rooted in export-oriented industrialization seek to manage the toxicity, unpredictability and political potency of socio-nature? The primary aim of this paper is to address these questions via a case study of the politics of waste management in the Irish Republic.

In the account offered below, both scalar strategies and struggles over scale will be shown to have lain at the heart of the politics of waste management in the Celtic Tiger. More specifically, the scaling of environmental governance has been both a medium for, and outcome of, an emergent cultural politics of 'waste'. Whilst social contests over the scaling of governance have tended thus far to focus upon dialectical relations between scale and political economy (Smith 1992; Swyngedouw 1997 2000; Brenner 1998 2001; Cox 1998; Macleod and Goodwin 1999), this paper will demonstrate that ecological projects too are fundamentally produced by and implicated in the structuration of scale. In calling for dialogue between political ecological studies and recent work in geography that has sought to theorize scale as a social process, the paper hopes to contribute towards the development of a wider political ecology of Tiger states.

The paper will be organized around three sections. In the first section, recent literature on, firstly, the political ecology of capitalism and, secondly, the political economy of Tiger states, will be drawn upon to work towards the specification of a political ecology of Tiger states. Focusing upon the critical period of 1996 to the present, the second section, which constitutes the main body of the paper, will then investigate the politics of Ireland's approach to waste management. The narrative presented will explicitly foreground the constitutive importance of scalar issues in the unfolding of the political process. Finally, in the third section, a critical reflection on the Irish experience will be used to generate a number key theoretical tenets that may prove useful for future studies interested in weaving together scalar issues with accounts of social struggles over transformed nature in Tiger economies.

\section{Towards a political ecology of Tiger economies}

\section{Society, nature and waste}

Geographers would now seem to be coming to terms with the full import of Neil Smith's (1984) call for the development of a dialectical ontology in which both nature and society are (re)conceived as being mutually constituted via historical and 
geographically specific modes of production. The development of a dialectical approach has been taken forward in impressive ways in the work of Erik Swyngedouw (1996 1999) in particular. Employing the highly evocative metaphor of the 'metabolism of social life', Swyngedouw has sought to demonstrate how 'social relations operate in and through metabolising the natural environment which, in turn, transforms both society and nature and produces altered or new socialnatural forms' (Swyngedouw 1999, 446). In resolving the nature/social binary in this way, Swyngedouw privileges the notion of 'historical nature' over 'first' or 'pristine' nature, and drawing upon Latour (1993), argues that what we take to be 'nature' is best conceived of as a part natural, part social, 'hybrid' or 'quasi-object'.

According to Noel Castree (1995), despite a rhetorical commitment to dialectical thinking, there is a tendency in some political-ecologies of the capitalist mode of production, in particular, to over-emphasize Smith's (1984) original concept of the 'social production of nature'. Society is often imbued with apparently omnipotent power to control nature and put it to the service of capitalist production. The virtue of true dialectical thinking, in contrast, is that natural processes must be seen to play a role in the constitution of social and political processes too. The materiality of nature must in itself be given agency. In fore-grounding this point, of course, one has to be careful not to treat nature as external to the dialectic. The materiality of nature has agency 'only in specific relation to the social relations it is imbricated in' (Castree 1995, 24).

Whilst many of capitalism's socio-natural environments are the result of intentional social practices, the importance of Castree's (1995) observation is best witnessed in what Benton (2000) refers to as the 'naturally mediated unintended consequences' of production. As a classic unintended 'quasi-object', waste reveals the importance of the materiality of nature par excellence. Although often confined to the sphere of the 'natural', the chemical, physical and biological processes at work in waste's socio-natural landscapes must be thought of as simultaneously exercising social, political, economic and cultural power. The chemical, physical and biological processes inherent in, for instance, the pollution of the water table via leaching from landfill sites, emissions of methane gas from compost heaps or the introduction of dioxins into food chains around thermal treatment facilities, must be conceived of as having a certain degree of agency in relation to prevailing social relations.

For O'Connor (1988), the threat of toxic environments to the reproduction of capitalist social relations has to be taken literally. In this context, waste might be approached in terms of the physical barriers it presents to the sustenance of a regime of accumulation. It is perhaps more useful, however, to interpret the threat of waste as one in which the cultural legitimacy of the regime of accumulation is brought into question (Benton 2000). It is here that representational practices become important. Kaika and Swyngedouw (2000) for instance, have shown how the technological apparatus that carry the material flows required to sustain contemporary cities (water towers, pumping stations, gasworks, sewage systems, dams and the like) have a rich cultural, ideological and aesthetic history (see also Gandy 1999). Likewise, in Strasser's (2000) Waste and want: a social history of trash, historical shifts in the treatment of the detritus of capitalist growth in the United States are related to the changing discourses through which waste has been codified.

That waste constitutes any kind of threat to the legitimacy of the late capitalist economy must be conceived of as deriving from the specific cultural readings of it that mark the contemporary period. In the case study to follow, struggles over the meanings attached to waste by different actors with different locations inside the Celtic Tiger will be placed at the heart of the socio-natural dialectic. Here, the meanings invested in 'waste' by different factions of capital, engineers, health officials, scientists, local and national politicians, the labour movement, journalists, community groups, Green NGOs and so on, will be shown to be an important ingredient in the story. It is through these cultural struggles that the materiality of waste will be shown to exercise agency as a source of threat to the social relations that have underpinned Ireland's remarkable economic development.

\section{Political economy of Tiger economies}

Which collection of countries is being referred to when the label 'Tiger' is invoked? A common conception is that it is in the South East Asian economies of Japan, South Korea, Singapore, 
Taiwan and Hong Kong, and more recently Thailand, Malaysia, Indonesia and the Philippines, that the characteristics of Tigerhood most reveal themselves. Although failing to live up to their full-blown counterparts, a number of 'intermediate' states such as Brazil and India have also traditionally been viewed as possessing Tiger qualities (Evans 1995). With the spread of the Asian flu and the derailment of the South East Asian economies since 1997 (Mallet 2000), nevertheless, the search for new Tigers has expanded and countries like Ireland and Israel, and even Chile, Mauritius and Botswana now also attract the Tiger tag.

If it were only to refer to the speed with which formerly backward countries have secured a role for themselves in the new international division of labour, the Tiger tag would be analytically empty. In order to avoid this charge, it is essential to appreciate that Tiger states are so recognized by virtue of their similar state structures and accumulation strategies (Evans 1995). Bello and Rosenfield (1990) attribute the success of the South-East Asian Tigers to the work of highly authoritarian state technocrats. Operating a form of command capitalism, these technocrats sought to embrace a developmental model that had at its heart a strong role for the state in building up indigenous industry into global players (Singapore aside, of course) (Kim 1998). Here the state played crucial midwifery (creating new seed companies), and husbandry (encouraging new firms to grow and enter international markets) roles (Evans 1995).

According to Evans (1995), key to the developmental state is the 'embedded autonomy' of state technocrats in networks of domestic industrial capital. The capacity of state technocrats to prod and poke indigenous companies in certain directions is dependent fundamentally upon the close social ties that bind state officials and leaders of domestic industry. The remarkable feature of these social ties is their reciprocity: not only does the state soak up the values of leading capitals, but it itself is involved integrally in inculcating into domestic industry such capitalist values as risk taking, innovation and competition. Most visibly embodied in the colossal South Korean chaebols, the state and capital in a very real sense are woven together in the pursuit of rapid growth.

The concept of 'embedded autonomy' is of pivotal significance to any understanding of the response of the developmental state to ecological crises. Given that the state is wedded to a growth coalition that includes powerful constituencies from industrial capital, any movement towards the environmental agenda would require something of a Gestalt switch. Ecological projects are simply incommensurable with a mind set borne out of deeply woven relationships with the national industrial bourgeoisie (Reardon-Anderson 1997). Against this backdrop, unless it dismantles its relationships with elites, the instincts of the developmental state will be to preserve the accumulation strategy and absorb ecological challenges in such a way that the interests of industrial capital are not threatened.

As the label 'Tiger' increasingly came to be associated with Ireland, so the country's growth strategy came increasingly to be compared with its South East Asian counterparts. Immediately, it became obvious that Ireland's experience was different. According to O'Hearn (1998 2000), Irish growth has not been steered by an interventionist state, but instead has been lubricated by a neoliberal state that has secured growth by creating a macro-economic environment conducive to the attraction of leading United States trans-nationals. Against O'Hearn however, O'Rain (2000) has cautioned against the all too easy rejection of the concept of the developmental state. Ireland's approach to the global economy must be read in terms of its efforts to both attract and embed trans-national investment and to nurture the development of local post-fordist complexes until they grow to become global players. In so doing, the Irish state has doubly embedded itself in networks of innovation within foreign trans-nationals (via, for instance, the Industrial Development Agency) and indigenous companies (via, for instance, Enterprise Ireland).

In place of the highly centralized and interventionist roles played by state technocrats in South East Asia, however, the Irish state has operated with a more flexible and decentralized command structure and has exercised a much lighter touch. For O'Rain, O'Hearn's thesis that Irish growth has derived from a neo-liberal state is mistaken and the concept of the developmental state remains a useful one. Nonetheless, whilst the South East Asian economies are characterized by a Bureaucratic Developmental State, Ireland, O'Rain argues, has grown under the governance of a new type of Flexible Developmental State. 
O'Rain's (2000) concept of the Flexible Developmental State provides a useful backdrop to the study of the politics of environmental management in Ireland. If the backbone of the Celtic Tiger is a doubly embedded state apparatus, energized by a growth strategy seeking to both ground transnational capital and globalize key types of indigenous capital, then it is clear that any environmental restrictions placed upon these constituencies will be problematic. The socio-natural environments produced by the Celtic Tiger must be managed, therefore, in such a way so as to preserve the chosen accumulation strategy. To the extent that Ireland's growing waste problems cannot be so effectively dealt with, the legitimacy of those interests that have benefited most from rapid growth risk being called into question.

To date, the bulk of critiques of the developmental state (whether they be Bureaucratic or Flexible) have been class based and have focused upon the unequal division of the national product. The Celtic Tiger has not proven to be an exception to this rule and the bulk of critical readings to have been published to date have attempted to spotlight such issues as the division of national wealth, labour market inequalities, the continued backwardness of the west of Ireland, growing social polarization in Irish cities, deepening inequalities in access to services, and the plight of asylum seekers and refugees (Breathnach 1998; Crotty and Schmitt 1998; O’Hearn 1998 2000; Tansey 1998; Allen 1999a 1999b 2000; Sweeney 1999; MacSharry and White 2000; Murphy 2000; Tallon 2000; Memery 2001; O'Leary 2001). In moving towards the case study, it is essential to end this section by noting that ecological and class based critiques are not mutually exclusive. In the spirit of the dialectical approach advanced herein, one purpose of this paper is to augment class-based critiques of the developmental state with a focus on the ecological impacts of rapid growth that is alert to Harvey's (1996, 182) insistence that 'all ecological projects (and arguments) are simultaneously political economic projects (and arguments) and vice-versa'.

\section{The politics of waste management in the Celtic Tiger}

\section{Background}

There can be few spectators of economic affairs who have remained unimpressed by the rapid growth of the Irish economy since 1993 (Figure 1). Ireland, it would seem, has moved from being one of Europe and the OECD's poorest nations to being one of their strongest performers (Dunford and Smith 2000). To some, the recent downturn in the United States economy and the global economic problems caused by the terror strikes in Manhattan on 11 September 2001 both signal the end of Ireland's remarkable burst of growth. According to Bank of Ireland (2001) estimates, growth in Ireland's GNP has fallen from 10.4 per cent in 2000 to 6 per cent in 2001 and looks set to fall further to 4.5 per cent in 2002. Likewise, the OECD (2001b) notes a fall in GDP from 11.5 per cent in 2000 to 5.6 per cent in 2001. While predicting a further fall in GDP to 3.7 per cent in 2002, however, the OECD predicts that a recovery in the world economy will restore Irish growth rates to 6.4 per cent in 2003. Whilst it is true that the Irish economy has struggled to maintain its dazzling performance of the late 1990s, it must be noted that it has managed to weather the storm of global economic recession as well as any country, and looks set to resume impressive rates of growth from a higher base when global events improve.

Accompanying rapid economic growth, however, has been a deterioration in the quality of Ireland's environment. According the state's own millennium review of the environment (Environmental Protection Agency 2000a), Ireland is under increased threat from growing mountains of waste, water pollution, greenhouse gas emissions, natural resource depletion and diminishing urban air quality. Without question, waste has emerged as the most controversial environmental issue in contemporary Irish politics. The Celtic Tiger, it would seem, is leaving ever yet greater quantities of detritus in its wake. Figure 2 reveals trends in waste production in Ireland from 1995 to 1998. Non-agricultural wastes would appear to have grown dramatically by over 37 per cent. In absolute terms, industrial wastes would appear to have grown fastest, but in percentage terms, the growth of construction and demolition, hazardous and municipal wastes, is also noteworthy.

By 1996, it had become obvious that Ireland's already antiquated waste management infrastructure was ready to collapse under the roar of the Celtic Tiger. A reserve function of local government, waste management was overwhelmingly conceived in terms of waste disposal. Given their relative cost effectiveness, landfills served as the 


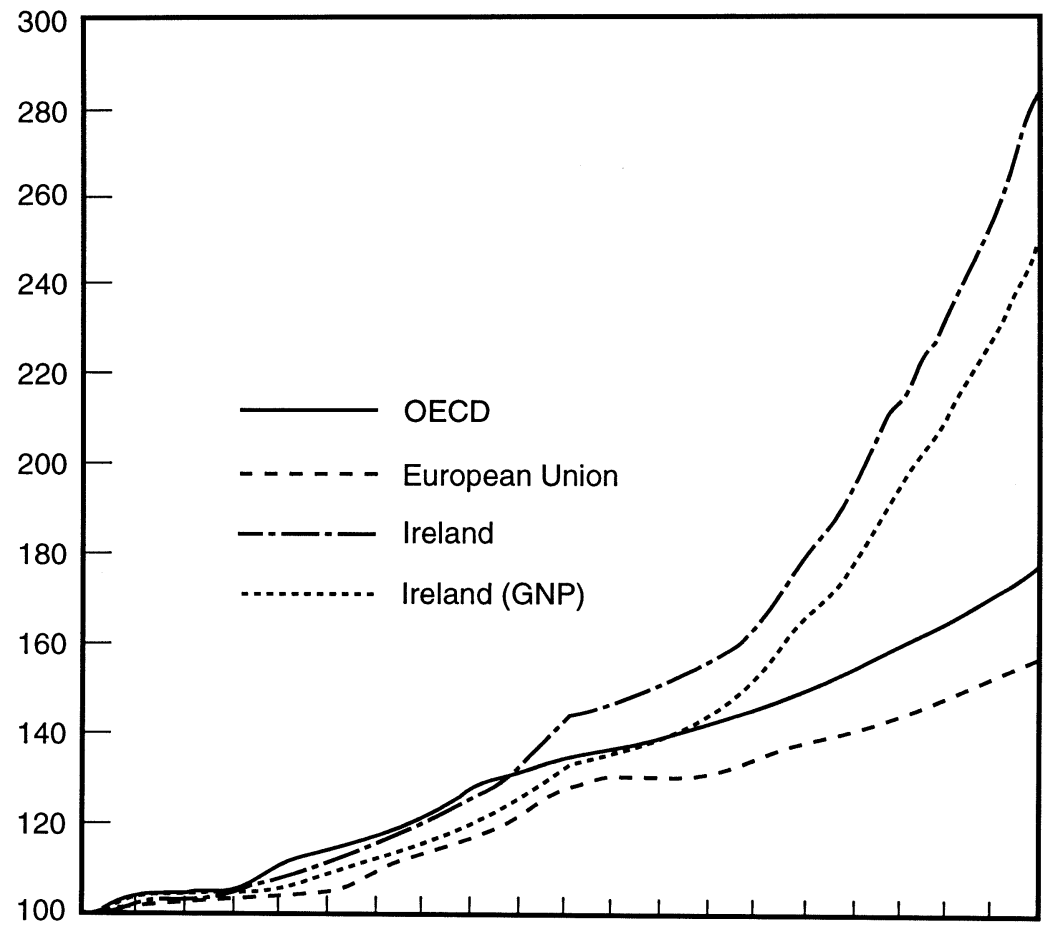

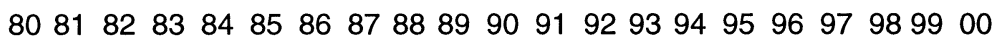

Figure 1 Ireland's economic performance in context: real output (indices: 1980=100) Source: International Monetary Fund $(2001,4)$

dominant method of disposing of waste and the country was largely bereft of any large-scale thermal treatment facilities (Tables I and II). The existing supply of landfill sites was being placed under intolerable strain by rapid economic growth. It is in the speed with which weakly developed institutions and infrastructure have been overwhelmed that one gets a glimpse of the distinctively Tigerish nature of Ireland's waste problems.

The pressure that increased waste streams are placing on existing landfill sites has been compounded by the limited life expectancy of many sites (Figure 3). Of the 87 local authority landfills reported to be receiving municipal waste in 1995, only 76 were in operation by 1998 (Environmental Protection Agency 2000b, 68-70). By mid 2000, a further 26 had ceased accepting waste, leaving only a total of 50 active local authority landfill sites. Of these 50, 38 are expected to close within the next ten years, with 25 having less than five years life expectancy. Reductions in public sector landfills were partly offset by an increase in private land- fills, from 31 in 1995 to 50 in 1998. Growing public opposition to landfill, however, means that it is unlikely that there will be a substantial growth in new private landfill sites in the near future.

\section{Constructing a narrative of the politics of waste} management in Ireland

In 1996, against this backdrop, the Minister for the Department of Environment and Local Government launched a radical overhaul of waste management planning in Ireland. The new departure was first announced in the Waste Management Act, which came into effect in July 1996 (Department of Environment and Local Government 1998a), and was given more detailed expression in the Waste Management (Planning) Regulations of 1997, and the policy statement Waste Management, Changing our ways ..., published in September 1998 (Department of Environment and Local Government 1998b).

The purpose of this section is to use a case study of the politics of waste management in Ireland to 
Tonnes per annum

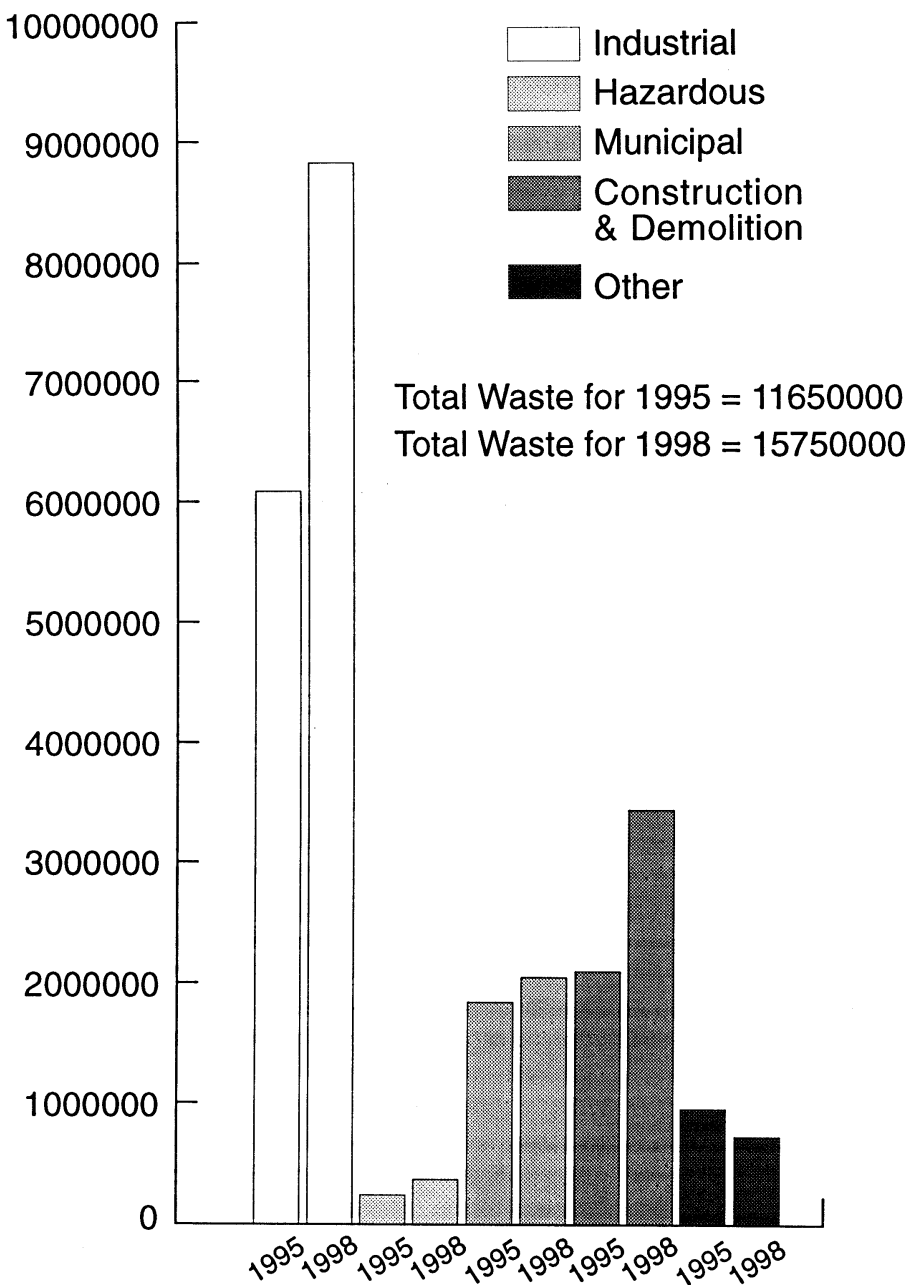

Figure 2 Non-agricultural waste production in Ireland, 1995 and 1998 Source: Environmental Protection Agency (2000b, 23)

generate theoretical insights of wider relevance to the task of constructing a political ecology of Tiger states. In so doing, the narrative presented below will fasten on the central importance of scalar strategies and struggles over scale in the constitution of an emergent cultural politics of waste. Discussion begins by locating Ireland within the European Union, and noting the significance of this supranational political institution in setting the environmental policy agenda in the country. Second, Ireland's decision to 'scale' waste management planning at the regional level will then be examined. Third, through a review of local and national political debates, the difficulties the Irish state has faced in completing the waste management planning process will be considered. Finally, the draconian measures introduced in July 2001 in the form of the Waste Management (Amendment) Bill will be examined as an illustration of the extremes the national coalition government has been prepared to go to in order to sustain its flagging scalar strategy.

Constructing a narrative of this breadth presents a number of important methodology challenges. 
Table I Management of selected waste streams, 1998

\begin{tabular}{|c|c|c|c|c|c|c|}
\hline Waste stream & $\begin{array}{c}\text { Disposal } \\
\text { Total }\end{array}$ & $\begin{array}{l}\text { Disposal } \\
\text { Landfill }\end{array}$ & $\begin{array}{l}\% \text { of each } \\
\text { Disposal } \\
\text { Incineration }\end{array}$ & $\begin{array}{l}\text { vaste strean } \\
\text { Recovery }\end{array}$ & Exported & $\begin{array}{c}\text { Unspecified/ } \\
\text { unreported }\end{array}$ \\
\hline Industrial & 74.1 & 69.4 & 0 & 25.9 & 0 & 0 \\
\hline Hazardous & 18.8 & 8.6 & 4.8 & 28.1 & 26.9 & 26.2 \\
\hline Municipal & 91 & 91 & 0 & 9 & 0 & 0 \\
\hline $\begin{array}{l}\text { Construction and demolition } \\
\text { (including dredged spoils) }\end{array}$ & 98.8 & 78.6 & 0 & 1.2 & 0 & 0 \\
\hline
\end{tabular}

Notes: The EPA note that the amount of construction and demolition waste going to landfill is exaggerated since a substantial percentage of the material is put to beneficial use at the landfill location, either as construction material for the construction of roads and berms or as cover and capping material. The large discrepancy between the total amount of construction material disposed of and the percentage that goes to landfill is accounted for by the dumping at sea of dredge spoils from harbour projects

Source: Calculated from Environmental Protection Agency (2000b, Ch. 3)

Table II Methods of disposal of municipal waste in the EU

\begin{tabular}{lcccccc}
\hline Country & Year & \% Disposed & Landfill & Incineration & \% Recycled & Other \\
\hline Austria & $1996 / 97$ & 60.5 & 32 & 15.5 & 31.7 & 7.9 \\
Belgium & 1996 & 71.9 & 32.4 & 24.7 & 28.1 & 0 \\
Denmark & 1997 & 85.5 & 12.3 & 57.7 & 14.0 & 0 \\
Finland & 1994 & 77.1 & 71.4 & 2.3 & 33.3 & 0 \\
France & 1995 & 104.1 & 46.1 & 49.8 & 1.9 & 0.4 \\
Germany & 1993 & 74.2 & 51.3 & 17.3 & 23.3 & 2.5 \\
Greece & 1997 & 91.3 & 91.3 & 0 & 7.9 & 0 \\
Ireland & 1995 & 92.4 & 92.4 & 0 & 7.6 & 9 \\
Italy & 1997 & 95.5 & 90.2 & 5.3 & $\mathrm{n} / \mathrm{a}$ & $\mathrm{n} / \mathrm{a}$ \\
Luxembourg & 1996 & 103.6 & 50.0 & 51.0 & 93.2 & 0 \\
Netherlands & 1996 & 75.8 & 20.3 & 30.9 & 16.7 & 7.5 \\
Portugal & 1997 & 100 & 95 & 0 & 0 & 0 \\
Spain & 1996 & 97.0 & 76.8 & 4.6 & 0.6 & 0 \\
Sweden & 1994 & 81.3 & 37.5 & 40.6 & 15.6 & 0 \\
UK & 1996 & 93.5 & 83.8 & 8.5 & 5.8 & 0.8 \\
& & & & & & \\
Average EU15 & & 86.9 & 58.9 & 20.5 & 19.9 & 1.36 \\
\hline
\end{tabular}

Notes: Because of recycling and because treatment methods are not always mutually exclusive, the total amounts collected and the sums of the treatment methods are not necessarily the same. Averages for 'recycling' and 'other' categories relate only to EU 14. When interpreting this table, it should also be borne in mind that the definition of municipal waste and the surveying methods used vary from country to country. Note also, data for Luxembourg looks particularly strange because total amounts exclude separate collection

Source: OECD $(1999,167)$

Interest in undertaking empirical research into struggles over the environment and the scaling of governance demands immersion into the messy worlds of international, national and local environmental politics and disputes. In the midst of the battery of discourses that one encounters therein, however, it is easy to lose a sense of perspective: who are the key actors in the debate and what are their roles and powers?; what weight do different points of view really carry?; which sources of evidence are more crucial than others? In making these choices, there is a risk that the author might be accused of cherry picking, selecting those bits and pieces of empirical events that suit the case being developed.

Of course, in the final analysis the narrative offered herein ultimately stands as a reconstruction of events, an outcome of a complex process of 


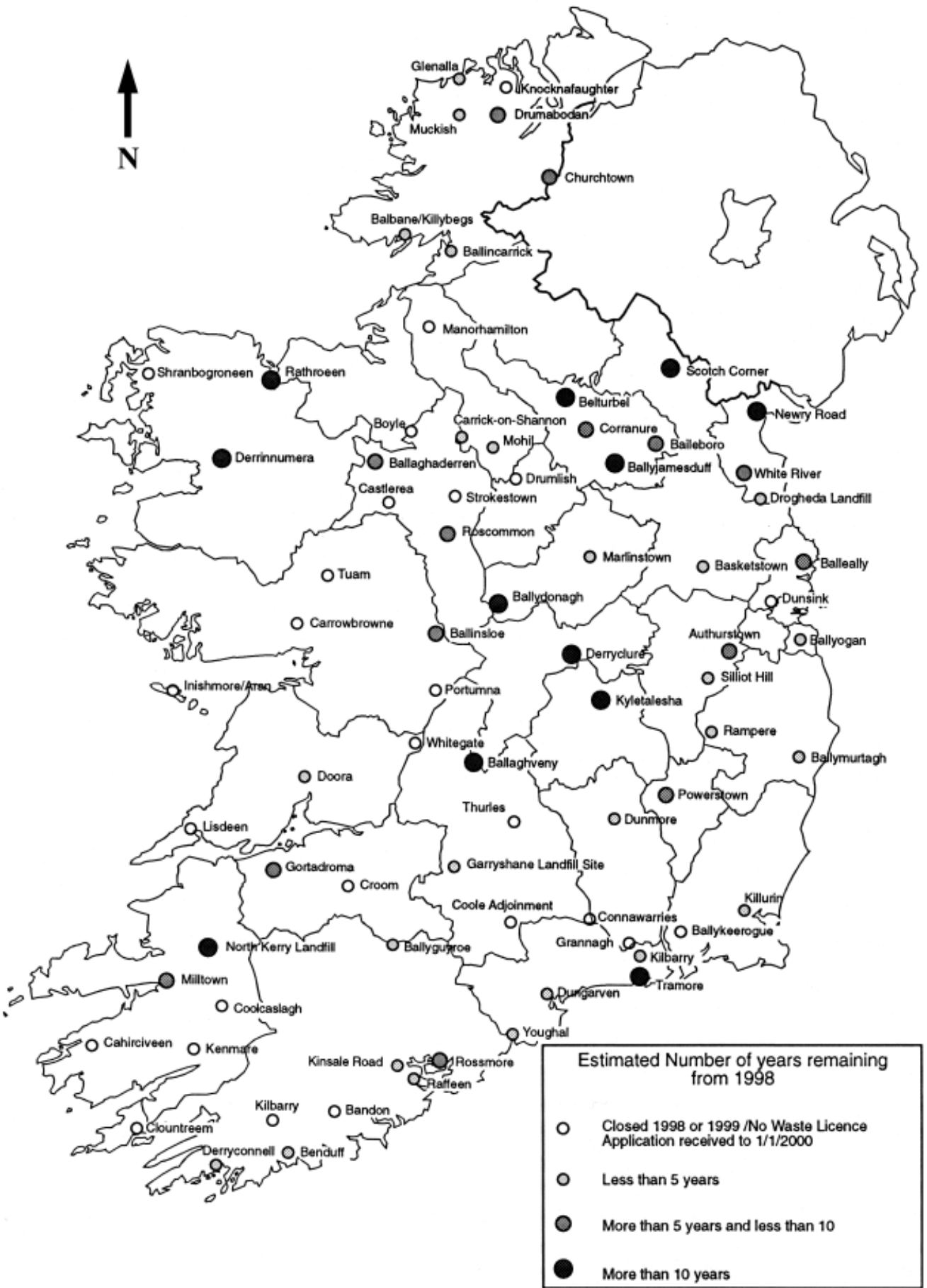

Figure 3 Remaining lifespan of active local authority landfills in Ireland Source: Environmental Protection Agency (2000a, 116) 
analytic induction. Nevertheless, in the quest for balance and in the interests of constructing a tale that might resonate with a wider audience, a large variety of research sources have been consulted. In a methodological approach that might best be termed 'exhaustive triangulation', every effort has been made to ensure that the chronological unfolding of events has been fairly conveyed, that the seriousness and content of conflicts has been adequately represented, and that all the key voices in waste management planning in Ireland have been included. The persuasiveness of the story told herein ultimately rests on how rich and rigorous readers judge the analysis to be.

Beyond the raft of official documents, brochures and web pages, which are fully sourced throughout, three additional sources of data have been used. First, every copy of The Irish Times and Irish Independent published between 15 July 1996 and 31 December 2001 was reviewed, and further information was sourced from local newspapers where relevant. ${ }^{1}$ Second, copies of all debates held in the Houses of the Oireachtas on waste management planning between 1 January 1998 and 31 December 2001 were obtained. This material covered all relevant debates held in the Dáil (lower house) and Seanad (upper house) and associated speeches and press releases, and all relevant Parliamentary Committee Meetings. $^{2}$ Finally, a total of seven semi-structured interviews/field visits were undertaken in January and November 2001 involving key actors involved in debates over the waste management strategy. ${ }^{3}$

In reading the following account, readers might also benefit from a brief background to the Irish state. The Irish state consists of an upper chamber, the Seanad and a lower chamber, the Dáil. To pass into law, Bills have to proceed through both houses. Although there are various routes through which Senators are chosen, it is normal for members of the Seanad to declare an affiliation to a particular party. Members of the Dáil (TDs) are democratically elected in the course of national elections. Ireland is unique in that the two dominant political parties are both right of centre Fianna Fáil and Fine Gael. Although relatively weak, the Labour Party and Sinn Féin offer the main voices of opposition from the left. Currently, the Fianna Fáil Party and the smaller Progressive Democratic Party sit in a weak coalition government (Table III).
Table III Members of the 28th Dáil as of 27 June 2001

\begin{tabular}{lc}
\hline Party & No. of seats \\
\hline Fianna Fáil & 75 \\
Fine Gael & 54 \\
Labour & 21 \\
Progressive Democrats & 4 \\
Green Party & 2 \\
Socialist Party & 1 \\
Sinn Féin & 1 \\
Others & \\
Total & 166 \\
\hline
\end{tabular}

Note: A Fianna Fáil/Progressive Democrat coalition controls the government, but requires the votes of four Independents to carry a vote

\section{Tigers and supra-national governance}

One problem of the excessive focus upon the South East Asian Tigers has been an under appreciation of the role of supra-national polities in shaping the political ecology of the developmental state. Whilst inadequate (Low and Gleeson 1998), the importance of existing supra-national institutions should not be underestimated. Most of the Tiger states, for instance, were among the 150 countries that endorsed Agenda 21 at the Earth Summit in Rio de Janeiro in 1992. Whilst Agenda 21 has not been without consequence in Ireland, it has been the country's relations with the European Commission that have been of greater import. Alongside fostering competition and cohesion between member states, the European Commission foregrounds sustainable development as the third pillar of its approach to community development. This interest in the promotion of sustainable development has recently been affirmed in the Commission's 'sixth environmental action programme' (European Commission 2001).

As a supra-national institution, the European Commission can exert a level of environmental control that member states would find difficult introducing by themselves. Through its various directives, the Commission has indeed shaped approaches to environmental regulation within member states. Although altered in the course of a review in 1996, the main tenets of the European Commission's policy on waste management can be dated to 1989 when the Community strategy for waste management was adopted. Three pieces of legislation to have derived from this strategy form the backbone of the Commission's policy. These are 


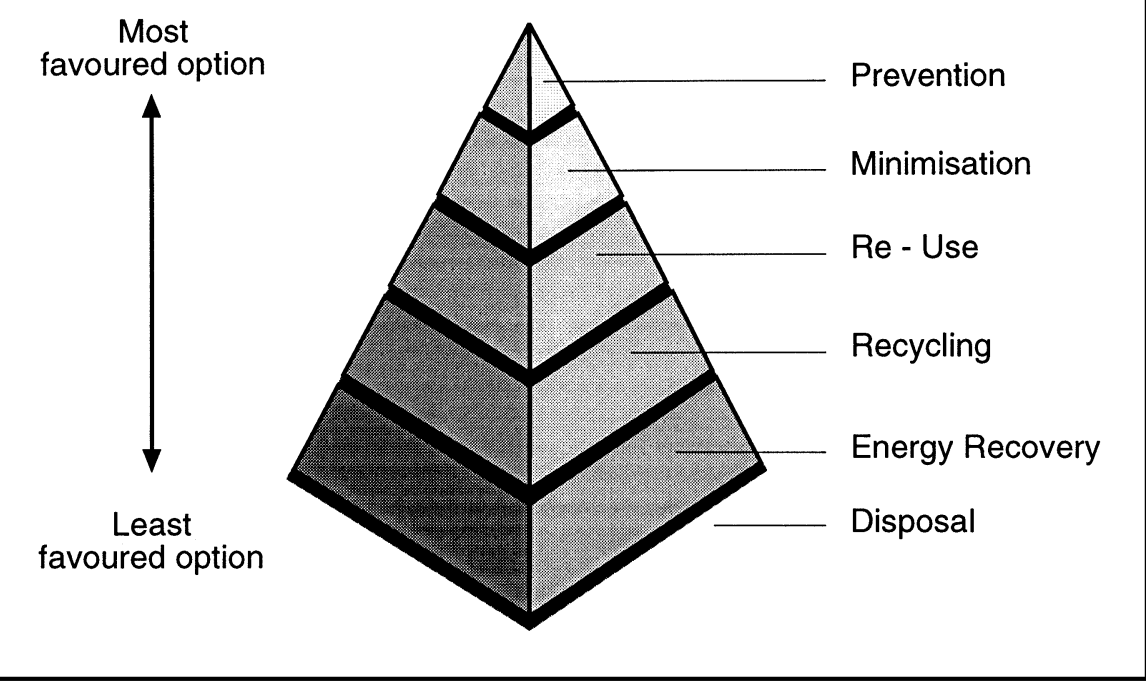

Figure 4 The waste management hierarchy Source: Environmental Protection Agency (2000a, 1)

the Waste Framework Directive, the Directive on Hazardous Waste and the Regulation on the Supervision and Control of Trans-Frontier Waste Shipments (European Environment Agency 2000). The general legal framework provided by these three pieces of legislation is supplemented by a number of more specific directives, dealing with particular waste streams (for example, packaging waste, batteries and accumulators, waste oils etc.), and setting safer technical standards for waste disposal and treatment facilities such as landfills and incinerators (European Environment Agency 2000).

Of greatest interest here is the Waste Framework Directive. From this directive has come the famous concept of the waste management hierarchy (Figure 4). This sets a list of priorities for dealing with waste. Priority must first be given to waste prevention and minimization through the application of technologies that produce cleaner production processes and that reduce packaging wastes produced at the point of consumption. To the extent that even the most efficient systems of production and consumption will generate waste, the next preferred options are the re-use and recycling of waste. Only in circumstances where it is impossible to re-integrate waste back into economic systems should the issue of waste disposal be considered. In the event that disposal of waste is required, waste to energy or thermal treatment facilities ${ }^{4}$ should be prioritized as causing less environmental damage than the landfill solution, which is identified as the strategy of last resort. The Waste Framework Directive requires member states to draw up waste management plans that detail how the waste hierarchy is to be implemented.

The transposition of the concept of the waste hierarchy into law in different member states, and the effect of such laws upon waste management practices on the ground, have been geographically variable (Davoudi 2000). In the remainder of this section, attention will be given to how the waste management hierarchy has grounded itself in the Celtic Tiger specifically. In so doing, I will argue that the Irish case has been marked by tumultuous struggles over ownership of the concept. In appropriating the waste management hierarchy, the Irish state has attempted to walk a tightrope between preserving rapid integration into the world economy whilst satisfying European Union membership rules. It is in these struggles that waste can be seen to have become an important threat to the legitimacy of Ireland's growth trajectory.

\section{The 'regionalization' of waste management} planning in Ireland

It was against the above backdrop that the Minister for the Department of Environment and Local 
Government launched a radical overhaul of waste management planning in Ireland in 1996. Central to the new strategy was the idea of an abrupt shift away from landfill and towards implementation, in so far as it was practicably possible, of the EU waste management hierarchy. At the forefront of charting the course of this transition was to be a series of new waste management plans. Crucially, these plans were to scale the problem of waste management primarily at the regional level. This devolution of responsibility from national government was to prove crucial in shaping the unfolding of the planning process in the months to follow. ${ }^{5}$

In seeking to understand the nature of the devolution envisaged by central government, it is essential to appreciate the scale division of the Irish state. The Irish state is comprised of two tiers, central and local, and as such, is one of the few states in Europe to lack any meaningful form of regional government (Coyle and Sinnott 1992; Laffan 1996; Boyle 2000). Moreover, central government dominates public life and local government is relatively weak. A British inheritance from 1898 legislation, local government rests primarily at the county level, and is comprised of a series of County Councils and County Boroughs. Until 1999, these bodies lacked any constitutional status. Historically, they have been allowed a limited range of competencies and have been subjected to strict ultra vires regulation. Under 5 per cent of GDP and only around 12 per cent of public expenditure is discharged through local government (Laffan 1996).

Given the existing scale division of the Irish state, concern was expressed that the small size of local authorities threatened to undermine their capacity to act. Consequently, the new strategy advocated a regionalization approach, whereby economies of scale were to be obtained through local authorities grouping together to formulate a regional plan. Given the lack of any meaningful regional structure, however, the groupings would have to be created. The need to manage the larger volumes of waste that would result from this institutional tinkering would facilitate the development of recycling/reuse infrastructure and would create a sufficient market to support small waste to energy facilities. It would also assist in the movement away from a large number of small and low technology landfills to a smaller number of larger and better run landfills - later to be stigmatized as 'super-dumps'.
Whilst a regionalization strategy was advocated, it was not forced upon local authorities and it was up to each authority to determine whether they wished to be in a regional grouping and, if so, which other local authorities they wished to link up with. In the end, a total of seven regional groupings comprising 31 of Ireland's 34 local authorities formed to prepare a joint plan (Figure 5). Both Wicklow and Kildare County Councils opted to remain outside regional plans in the hope that they might selectively buy into the Dublin regional plan at a later date. Finally, Donegal County Council was to join Northern Ireland in the preparation of a cross border plan.

In recognition of their lack of expertise in waste management planning, all the new regional groupings were obliged to employ specialist consultants to prepare draft plans. Once formulated, these draft plans were to go out for public consultation. Each local authority would then have to vote to accept the plan for their region and plans would be rendered illegal unless all members of the group accepted them. It was at this point that Irelandbased engineering consultants M. C. O'Sullivan and Co. Ltd, represented by Director Mr P. J. Rudden, began to emerge as important actors in the debate (Rudden 2000). M. C. O'Sullivan and Co. Ltd were commissioned to produce all but one of the draft regional plans.

It should be noted that in all cases in which they were involved, M. C. O'Sullivan and Co. Ltd embraced the ethos of reuse/recycling and all draft plans of their making had detailed recommendations on the types of infrastructure required to maximize reuse/recycling. Key to each plan, however, was the belief that it was unrealistic to think that reuse/recycling could solve all of Ireland's waste problems - even with the best will, a significant amount of waste would be required to be disposed of (Rudden 2000). Working alongside Danish consultants, COWI, and accepting EU thinking that waste to energy was a preferable method of disposal to landfill, key to all of the plans was a proposal to construct at least one thermal treatment facility in each regional grouping. To the extent that landfills were still required, plans worked towards a steady reduction in the total number of landfills and the creation of 'superdumps' with higher operating standards.

Draft plans prepared by M. C. O'Sullivan and Co. Ltd were published for public consultation in the course of 1997-1999. According to the 


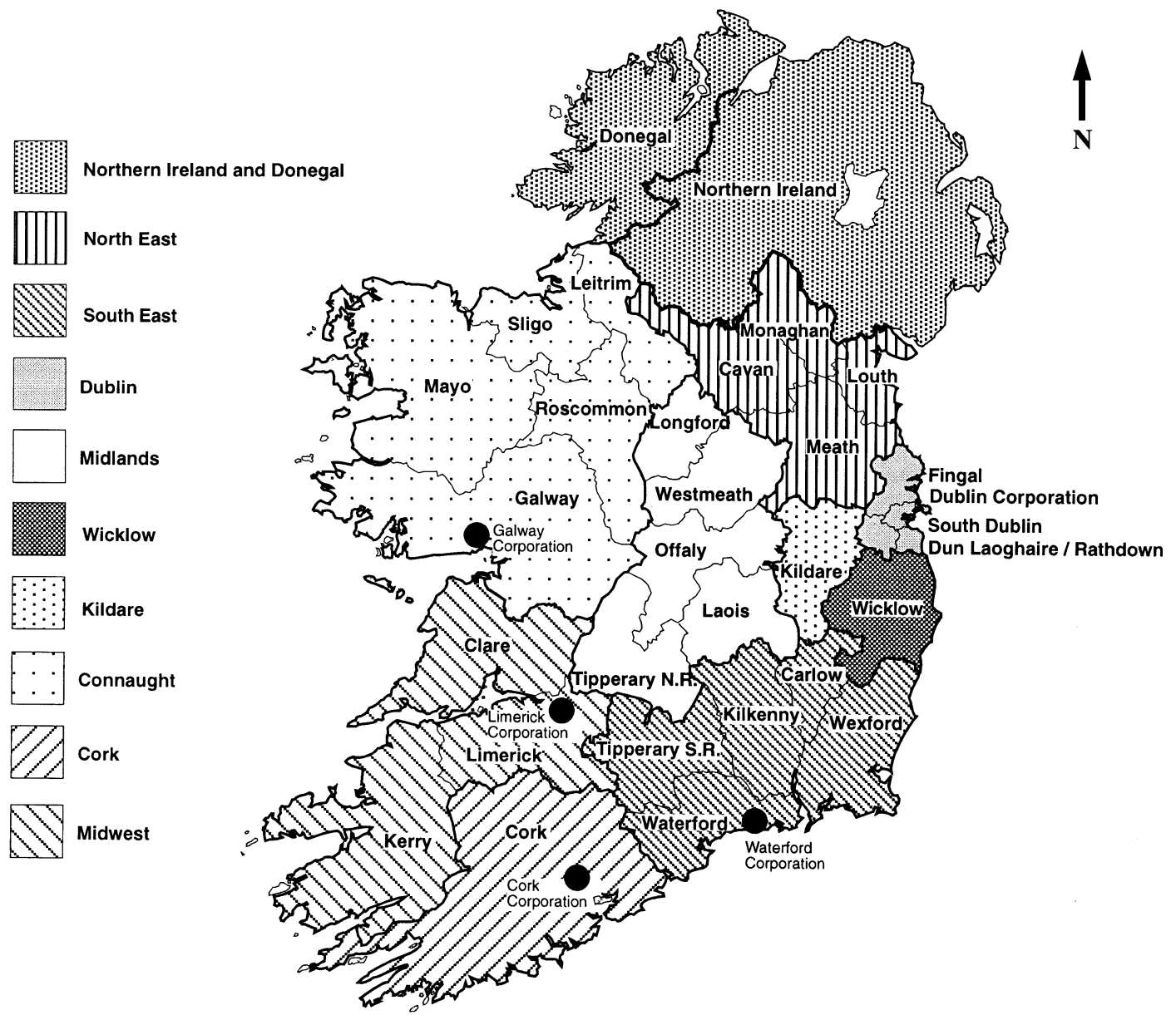

Figure 5 Regional waste management planning areas in Ireland 2001 Source: Irish Times, 10 January 2001, p. 9

Department of Environment and Local Government $(2000,29)$, a typical regional plan aims to recycle 51 per cent of total waste, dispose of approximately 27 per cent through incineration and use landfill for only 22 per cent (Table IV). In practice, however, some plans have had more modest recycling targets and thus have been forced to consider higher thermal treatment volumes. In the Midwest, North-East, Midlands, and Connacht, for instance, 45 per cent, 39 per cent, 37 per cent and 33 per cent of waste is planned to be thermally treated, respectively. ${ }^{6}$ Arguably, it has been the central role ascribed to thermal treatment in particular that has served to grind the process of formulating waste management plans in Ireland to a halt.
Table IV Typical waste disposal targets in the regional plans

\begin{tabular}{lccc}
\hline & $\%$ & $\%$ & $\%$ \\
Waste stream & Reuse/recycling & Thermal treatment & Landfill \\
\hline Municipal waste & 45 & 52 & 3 \\
Industrial waste & 27 & 29 & 44 \\
C \& D waste & 80 & 0 & 20 \\
Total & 51 & 27 & 22
\end{tabular}

Source: Department of Environment and Local Government $(2000,29)$

For some critics, the 'scaling' of waste management at the regional level needs to be regarded as a fundamentally political exercise. ${ }^{7}$ By constructing 
a division of labour between central and local government, national politicians could create a distance between themselves and the difficult decisions that had to be taken concerning how economic growth needed to be managed and regulated. To interpret the scalar strategy as a strategic displacement of responsibility, however, is insufficient. In choosing to locate responsibility for waste management at the door of weak and fabricated regional groupings, the Irish state has arguably pre-determined that plans have opted for 'end of pipe' solutions.

It is unsurprising that plans have largely ignored, or under-specified, options at the top of the waste management hierarchy and have sought to naturalize the assumption that a substantial degree of waste disposal must be a core feature of waste management in the future. In scaling the management of waste at the regional level, for instance, the state has created new and viable markets for super-dumps and thermal treatment facilities. These options would simply not be tenable if each local authority was to be responsible for its own waste. On the other hand, projects that might make a serious contribution to addressing the most favoured prevention/minimization and reuse/recycling options arguably need to be led by national government. It seems unreasonable, for instance, to expect each local authority to possess the kind of 'sophisticated' knowledge of how ecotaxation schemes work, which would be required to force capitals into new production methods (Turner et al. 1998). Moreover, it seems unlikely that local authorities will be capable in themselves of nurturing substantial private investment in, for instance, reuse/recycling infrastructure.

By scaling ecological problems in a certain way therefore, and institutionalizing remedial measures accordingly, the Irish state has effectively ensured the legitimacy of the underlying regime of accumulation and has promoted certain kinds of interventions and foreclosed others. Far from being a practical or technical matter, the regionalization of waste management in Ireland has both been produced by and in turn worked to reproduce the developmental agenda. The result of this scalar strategy has been that the Irish state appears to be more concerned about organizing consent around what are acceptable levels of pollution, than radically attacking the roots of the economic policies and systems that generate problems of waste in the first instance (Taylor 1998).
Resistance to the new regional plans: 'culture wars' over waste

The Waste Management Act (1996) envisaged that the entire planning process should take no longer than four years, and thus that the implementation of plans should be under way by July 2000 at the latest. As early as February 1999, however, it was becoming clear that the four-year target might not be met. Of course, problems were aggravated by the fact that if one local authority in a regional grouping failed to endorse a plan, the whole plan was rendered void. As plans got bogged down, so the pressure on national government to intervene steadily increased. A review of Dáil and Seanad debates between February 1999 and March 2001 reveals an increasingly aggressive opposition, keen to condemn the lack of progress the government was making and demanding that decisive action be taken to push the process forward. ${ }^{8}$ Growing pressure on national government to act was further magnified in 1999, when the European Commission launched proceedings to take Ireland to the European Court of Justice and to impose financial penalties on the state for failing to ensure that waste management plans were in place.

Despite overt and covert bullying from central government, by late March 2001, a number of local authorities still refused to accept proposed regional plans. Three local authorities in particular, Longford County Council (Midlands group), Lough County Council (North-East) and Galway County Council (Connacht), had rejected plans in their entirety, holding up the remaining 12 local authorities in their groupings (Figure 5). Other local authorities meanwhile, such as Wexford County Council (South East) and Roscommon County Council (Connacht), had adopted plans only subject to potentially significant qualifications relating to the incineration option.

Against this backdrop, this section presents a reading of why the Irish State has found it difficult to put in place a series of regional waste management plans. In so doing, it argues that the failure of the state to 'force' plans through was rooted in its failure to win a series of culture 'wars' over waste. The politics of waste management planning in Ireland has played itself out largely as a cultural politics, in which waste has been variably codified by actors operating at a variety of different scales, including local communities, local and national politicians, green lobbyists, academics, engineers, scientists, health experts, journalists, cultural 
commentators, factions of capital and the labour movement. Three types of cultural conflicts have proven most contentious: the cultural politics of the Nimby label, the cultural politics of the toxicity of waste and the cultural politics of the location of waste in the Irish political economy.

The rise to prominence of these three culture wars over waste needs to be understood as being dialectically related to the regional scalar strategy adopted. In privileging 'end of pipe' solutions, the regional scalar strategy has set a tapestry upon which waste has been invested with certain kinds of meanings. If waste management had been scaled differently, and if plans had as a consequence opted for options at the top of the waste management hierarchy, arguably the following cultural conflicts might not have occurred at all, and if they did, they might have been less potent. Not only has the regional scalar strategy exerted causal effects on the ways in which waste is to be treated, but so too has it constituted a vital backdrop to the nature and virulence of contradictory cultural interpretations of waste.

Cultural politics of the NIMBY label Ireland is literally alive with local opposition groups protesting about both proposed incinerators and superdumps. ${ }^{9}$ As forms of what Harvey (1996) refers to as Militant Particularism, these groups have thrived under the 'regional' scalar strategy adopted by national government. At the outset, many of the Militant Particularist groups mobilized simply around NIMBY concerns. The prospect that their neighbourhood might have to play host to a regional incinerator or super-dump incensed many groups. Not only would the location of such facilities undermine residents' enjoyment of the quality of their living environment, but also house prices might be driven down. It is here that the first cultural reading of waste can be observed: waste as a negative externality that has the capacity to tarnish the amenity value of residential neighbourhoods.

Alert to the manner in which the label was being used as a smear, however, and assisted by both national environmental protest organizations (including the 'Waste Action Group' comprising 'Voice of Irish concern for the environment' and 'Earthwatch: Friends of the Earth Ireland'), and a number of international environmental activists, many local protest campaigns sought to escape the NIMBY tag by arguing against incinerators and super-dumps on, for instance, health and financial grounds. Seizing upon this shift, the government persistently accused residents' groups of using health and financial arguments to legitimate what was otherwise thinly veiled NIMBY-ism. Ridiculing community opposition, P. J. Rudden, Director of M. C. O'Sullivan and Co. Ltd, even claimed the existence of NOTEs (Not Over Their Either) and BANANAs (Build Absolutely Nothing Anytime Near Anybody) (Rudden 2000)!

In claiming that residents' groups are motivated primarily by NIMBY concerns, the government has also shown a willingness to connect opposition to waste management plans to wider debates about the corrosion of Irish national identity. In the light of rapid economic growth, there has been a vigorous debate in Ireland over whether material advancement has cultivated a demise of the Irish character. In an article published in the Irish Sunday Independent in December 2000, journalist Emer O'Kelly summarizes the fears that many cultural commentators have:

in our crass eagerness to celebrate economic success, it would seem that the act of celebration, rather than the quality or even the sanity of that celebration, is all that matters to us as a nation. Celebration is all around us; but little of it has a dignity or quality of thought. Our notions of success are almost all superficial and vulgar ... No longer do we wait for the manufacturers' built-in obsolescence to kick in: as soon as a new and more expensive model becomes available, whether it be a car, a television, a computer, or a video recorder, it is purchased. ${ }^{10}$

Public attitudes to waste disposal were frequently situated within such discourses on the erosion of the national character wrought by economic success. ${ }^{11}$ Whilst the public wanted the fruits of economic growth, it refused to accept the responsibility that accompanied it. In so doing, it laboured under the misapprehension of what Minister Noel Dempsey repeatedly referred to as the 'Paul Daniels solution' (waste could simply be vanished with the wave of a magic wand). The irresponsibility of the Irish public was made worse by the fact that they appeared happy to soil the natural beauty of the country. The imagery of Ireland as a remote and rural, sparkling green Emerald Island, blessed with fresh blue rivers and lakes, whose coastline was washed by the Atlantic Ocean, was drawn upon to highlight the violence that the detritus of a consumer society was doing. Waste was scarring a country blessed with an unusual endowment of nature's bounties. The 
'forty shades of green' were turning to forty shades of black. It is here, then, that a second cultural codification of waste emerges: waste as emblematic of the dilution of national pride and civic duty wrought by material advancement.

Cultural politics of the toxicity of waste For many local politicians, the potential health hazards of incineration and, to a lesser degree, super-dumps were the source of greatest difficulty. On the one hand, Militant Particularist groups, green NGOs and international environmental activists were presenting them with both scientific studies and examples of 'moral panics' in other countries that were leaning them against incineration. On the other hand, qualified engineers in the form of M.C. O'Sullivan and Co. Ltd were providing them with alternative scientific evidence and other kinds of international examples that were proving contradictory. Regional Health Boards, meanwhile, were unable to provide definitive answers (Midland Health Board 2000). Arguing that they were politicians and not scientists, local politicians wanted national government to produce an official research report on the health implications of incineration and super-dumps. ${ }^{12}$

Concerns about the health hazards of living in the proximity of an incinerator, in particular, focused upon the main contaminants released in the combustion process, dioxins. Airborne dioxins produced from incinerator plants, it was argued, were capable of affecting health both directly, through inhalation and indirectly, by becoming absorbed in the food chain. The problem of dioxins was compounded by the need to landfill slag laced with a number of dangerous heavy metals that remained after incineration. Both risks were seen as hazardous enough to merit a reconsideration of the incineration option. It is in these health concerns that a third cultural codification of waste emerges: waste as a toxic substance possessing serious health implications.

The initial response of the Government was to reject health concerns as alarmist. As the public panic over the health consequences of living close to an incinerator or super-dump spread, the government's dismissive attitude deepened. This was manifest most clearly in its reluctance to take responsibility for the production of a definitive scientific study. As local authorities were charged with the responsibility of accepting plans, it was up to them to compile scientific reports if they had concerns about incineration. The government would have no qualms if local authorities wished to submit a bid to the national Health Research Board to undertake a research project, but it itself wanted to remain autonomous from this process. ${ }^{13}$ If the government did commission a report, it would only be seen to be biased anyhow.

Whilst the official position sought to absolve the government from responsibility, Ministers at Department of Environment and Local Government did concede that they concurred with the view of the EU hierarchy, that thermal treatment was a preferable option to landfill. The dangers often associated with incineration were overblown and related to older technologies. If constructed according to the regulations imposed by the Environmental Protection Agency, thermal treatment plants ought not to pose any serious health risks. Other countries operated thermal treatment plants safely, waste to energy technology was developing daily, and the public had nothing to fear. In advancing the view that the toxic properties of waste could be rendered benign, a fourth codification of waste emerged: waste as an exemplar of the power of science, engineering and technology to bring nature under control.

\section{Cultural politics of waste as a public good the Irish}

political economy In 1978, amidst much acrimony, local taxes on households to cover the cost of waste collection and disposal were abolished. The revenue shortfall was made up out of a Rates Support Grant from central government. In 1983, however, local authorities were once again empowered to levy waste charges, with each authority free to determine their own level of charge (OECD 2000). Of those local authorities providing household waste collection in 2000 however, 11 (19\%) were still not levying charges for the service. In those that did, household charges were relatively low, whilst charges on commercial generators were often well below the true costs incurred. The consequence has been that waste collection and disposal has been largely subsidized out of general taxation reserves. In 1998, for instance, local authorities spent nearly IR $£ 100$ million on waste collection and disposal, but received a total income of IR $£ 50$ million from landfill gate fees and waste charges (OECD 2000).

It is against this context that the question of who was to finance the new regional plans was raised. If 
waste producers were not even covering the costs of waste disposal at the moment (revenue costs), where would monies come from to finance the new capital projects (thermal treatment plants, superdumps, recycling facilities etc.) envisaged in the regional plans? According to the National Development Plan 2000-2006 (Irish Government 2000), capital investment in the region of IR $£ 650$ million will be needed to upgrade Ireland's waste infrastructure. Of this sum, IR $£ 100$ million was to come from EU-Exchequer funds, IR $£ 100$ million from local government itself (via local taxes), and IR $£ 450$ million from the private sector (via public private partnerships). It is in the twin principles of 'polluter pays' taxes and 'public-private partnerships' that two further codifications of waste can be seen.

Debate over the introduction of the 'polluter pays' principle reached its zenith in April 2000. In response to a growing fear that there might be a loophole in the 1983 legislation allowing for local authorities to charge households for waste services, the government rushed through emergency legislation. ${ }^{14}$ According to the government, the legislation was needed in order to avoid any possible confusion regarding the central importance of the polluter pays principle. Waste producers could no longer expect to be 'subsidized' from general taxation funds. Both the Labour Party and Sinn Féin, and the national trade unions led by SIPTU ${ }^{15}$ reacted with fury. At the core of concerns from the left was the claim that the introduction of household and commercial charges would mean that ordinary working-class people and small commercial enterprises would be forced to pay the waste disposal bill created ultimately by big business. The taxation burden ought not to lie with 'consumers' who are situated at the end of the process. It is here that a fifth codification of waste emerges: waste as a site of class struggle in the ongoing political economy of the Irish taxation system.

Recognizing that waste taxes alone would never be sufficient to finance much needed infrastructural improvements, public-private partnerships were to be a cornerstone of all the waste management plans (Reaves and Barrow 2000). The introduction of the private sector was to herald a sixth way in which waste was to be represented. Once codified as a public externality that was the collective responsibility of society, waste was now to be privatized and viewed as a commodity in a number of emerging markets. Three particular types of waste markets were to be opened up. First, waste was to be treated as a 'raw material' in recycling markets. Given that the cost of recycled products often exceeds that of virginal materials, the role of the state was to subsidize the market to enable recycling companies to become profitable. Second, waste was to be treated as a source of energy capable of feeding into the national electricity grid. Given that the cost of transforming 'waste to energy' in thermal treatment plants is prohibitive, again the role of the state was to subsidize these plants to enable them to sell their output to the national power companies. Finally, waste was to be treated as an object to be disposed of. Here the role the state was to encourage the private sector to upgrade technology levels in private landfill sites by not subsidizing waste disposal and by allowing the full rules of the market to have effect.

\section{Draconian measures or a necessary evil? In defence of a flagging scalar strategy}

By March 2001, it had become apparent that the refusal of some local authorities to accept regional waste management plans had effectively brought the entire planning process to a halt. European Union fines looked imminent. And all the while the Celtic Tiger was continuing to deposit ever increasing volumes of detritus in its wake. It was becoming clear that drastic action was needed. From across the political spectrum, albeit for different reasons, a consensus was growing that the lack of strong national leadership was the problem. Regional groupings of local authorities were simply too weak to be capable of solving Ireland's growing waste management problems.

Fearing that industry might 'choke on its own waste', the Irish Business and Employers Confederation (IBEC), the voice of the Irish business community, for instance, made repeated calls for the establishment of a National Waste Management Authority (IBEC 2000). For IBEC, such an authority would safeguard the proposed use of 'end of pipe' solutions such as thermal treatment plants. Calling for a moratorium on incineration construction, an abandonment of household waste charges, and state investment in and control over new waste management infrastructure, the Labour Party (2001) likewise advocated the need for a National Waste Management Authority. For the Labour Party, Sinn Féin and SIPTU, however, only 
a national authority would have the clout to pursue options further up the waste management hierarchy.

Against the grain of these alternative proposals, the Fianna Fáil/Progressive Democratic coalition decided that the best policy would be to try to force the regionalization strategy to work. They did so via the Waste Management (Amendment) Bill 2001. ${ }^{16}$ This Bill, which proposes a number of draconian measures designed to bring the existing planning process to completion, has proven to generate further controversy. At the centre of the Bill was a proposal to transfer the power to adopt a waste management plan away from locally elected members of local authorities to local authority managers. By giving executive authority to the local civil service machinery, which was insulated from electoral pressures, the Minister hoped to 'remove any perceived obstacles to the effective implementation of regional plans'. If local counsellors lacked the nerve to push through unpopular plans then responsibility to make difficult decisions required to be relocated elsewhere.

Not surprisingly, the proposal generated a furious response from both local politicians and national opposition parties (in particular Fine Gael and Labour) concerned about local democracy. To some, the Minister seemed more determined to force through unpopular plans than to seriously take on board local concerns. According to Fine Gael Senator Fergus O’Dowd:

This Bill goes to the heart of local democracy ... By introducing this Bill, the Minister is taking away from the representatives of the local people a democratic right and a reserved function of elected members to decide how their waste will be managed and giving it to a county manager who does not have any knowledge or professional competence in this area, is not responsible to the public, and who will not stand for election. ${ }^{17}$

Responding to these allegations, Minister Noel Dempsey argued that the Bill actually strengthens local democracy because it restricts the capacity of a minority of local authorities to slow down the capacity of the majority of local authorities who have already accepted plans to get these plans implemented.

After a stormy passage through the Seanad in March and April 2001, the Bill was eventually read in the Dáil in early July 2001. Much to the consternation of critics, the government had left the Bill to the last week of Dáil business before the summer recess, a time when many politicians had already left Dublin. Even so, it was passed only by a narrow majority of TDs (56 to 46) on 6 July 2001. Following a final report to the Seanad on 10 July, the Bill was formally passed into law on 17 July 2001. The timing of this passage was opportune. On 12 July 2001 the European Court of Justice opened a hearing into Ireland's failure to comply with European Union directives. In the light of the Waste Management (Amendment) Bill 2001, however, and given promises that this Bill would now allow the Irish state to complete the process of preparing regional waste management plans, the European Court of Justice agreed to adjourn the European Commission's case against Ireland.

Despite the passage of the Bill, a number of outstanding problems look set to stay on the horizon. Will local authority managers have the courage or arrogance to accept plans that have been rejected by local politicians? If local authority managers decide to accept plans, what new forms of opposition will arise to the un-democratic imposition of incinerators and super-dumps on communities? There is already evidence that those managers that have sought to force through unpopular plans can expect messy legal challenges and public demonstrations on the streets. ${ }^{18}$ Will the new strains on the relationships that exist between local communities, local politicians and the local civil service have the potential to grind the work of local authorities to a halt? On the other hand, if managers side with local politicians and continue to reject plans, what options remain open to the Minister? In such an eventuality, will a National Waste Management Authority not be required to be instituted and the problem of waste management planning re-scaled to the national level (Labour Party 2001)? Will Ireland have time to go back to the drawing board before the European Commission finally imposes financial penalties?

\section{Conclusions}

In so far as they are marked by unique accumulation strategies that have delivered remarkable rates of economic growth, this paper has argued that Tiger economies are characterized by distinctive transformations of nature. The threat 'transformed nature' poses to the broad range of constituencies wedded to the developmental state has been the subject of attention in the paper. In 
closing, it is worthwhile pointing to three themes of broader theoretical interest to stem from the above case study: the ascription of agency to socionature; the role of 'scale' in political ecological conflict; and the utility of the concept of the developmental state in the interpretation of the political economy of Tiger states.

First, in the dialectic between political economy and nature, this paper has insisted that the materiality of nature be given attention. Whilst produced by unique configurations of capitalist social relations, the socio-natural environments prevalent in Tiger economies must be treated as exercising agency in relation to these same social relations. The narrative presented above testifies to the manner in which the rise of the Celtic Tiger from 1993 has given birth to the spectre of new socio-natural environments such as 'super-dumps', thermal treatment plants and dioxin polluted food chains, illegal fly tips, littered streets, compost heaps and public recycling facilities. As 'naturally mediated unintended consequences' (Benton 2000) of the country's rapid integration into the world economy, these socio-natural environments have clearly posed a threat to legitimacy of the social relations that have lain behind the accumulation strategy that has delivered Tigerhood status.

In making this claim, it is important to reflect upon the different forms of agency that are being ascribed to socio-nature herein. At one level, it is instructive to view growing mountains of waste as forcing debates to take place that certain factions of capital and political constituencies would prefer to avoid. Waste is there, it is growing and it represents a highly visible blot on the landscape. It demands attention. Moreover, it is not a static product. Bubbling beneath the surface of landfill sites, incinerator emissions and residues, fly tips, compost heaps and so on, are a range of chemical, physical and biological processes. Rooted inside prevailing capitalist relations of production and consumption, these physical processes ceaselessly jockey with capital, labour and state actors - often in unpredictable ways. Socio-nature has agency precisely because it impinges upon, disturbs, outwits, and occasionally poisons the very accumulation strategy that gave birth to it.

Whilst the physical properties of waste exercise agency directly, the threat posed by transformed nature to the prevailing political economy has been theorized in this paper more in terms of a cultural politics. Waste has served to generate a significant degree of controversy in Ireland largely because of a failure of the Irish state to win a series of 'culture wars' over how it ought to be conceptualized. Competing readings of waste produced by local, regional, national and international politicians, different cohorts of capital and business lobbies, voices from the trade union movement, green NGOs, local community groups, journalists, engineers and health professionals, and so on have meant that conflicts over waste have been rooted in how it is read: as a threat to the amenity value of residential neighbourhoods, as a toxic substance and health hazard and as a public good in the Irish political economy. Socio-nature has agency therefore, not only in a literal sense, but also because of the various ways in which it is imagined.

Second, crucially, however, the extent to which the cultural politics of waste has emerged as a threat to Ireland's chosen accumulation strategy has been shown to be mediated by scalar processes. Scalar strategies and struggles over scale have run to the heart of the Irish case study. As a supranational polity, the European Commission has found itself able to insist upon standards of environmental regulation that individual member states would find hard to pursue on their own. Rooted in the concept of the waste management hierarchy and using the instrument of the EU Directive, the European Commission has placed pressure on Ireland to formulate policies to deal with the fundamental causes of waste production in the first instance.

As an example of a Flexible Developmental State, however, the Irish state has found it extremely difficult to respond to pressure from the European Commission in a meaningful way. Located in a state apparatus that has doubly embedded itself within networks of both transnational and indigenous capital, the Minister for the Department of Environment and Local Government has found it difficult to address the problem of waste by attacking the underlying accumulation strategy that has generated it. In attempting to resolve the contradictory position it has found itself in, the Irish state has chosen to 'scale' the problem of waste management at a regional level. This scalar strategy has conditioned, in a fundamental way, the nature of the grounding of the waste management hierarchy in the country producing end of pipe solutions.

A core thesis advanced in this paper then is that into the interface between political economy and 
nature, must lie debates about the scaling of environmental governance and the governance of environmental scaling. Whilst theorizations of the role scalar processes in the constitution of the political economy of capitalism are now well developed, this paper advocates a greater need for dialogue between such theorizations and scholars interested in the political ecology of capitalism. Specifically, at the heart of the development of a political ecology of Tiger states must lie a reflection on the dialectical relations between metabolic transformations of nature and the structuration of the scale division of the developmental state.

Finally, Evans' (1995) concept of the developmental state has been viewed in this paper as pivotal to any understanding of the response of Tiger states to ecological threats. Nonetheless, in recognition of the many different guises such a state apparatus might take, use has been made of O'Rain's (2000) recent depiction of the ideal types of the Bureaucratic and Flexible Developmental States. The virtue of the concept of the Flexible Developmental State in particular is that it resonates with conventional wisdom that the state is not a centred entity. Whilst the literature on Bureaucratic Developmental States suggest that it is precisely the strong command style of state organizations that creates vibrant economic growth, there is a danger in using such a concept of falling into the trap of assuming that the state is a coherent and monolithic entity. Of course, in the above analysis the manner in which the Department of Environment and Local Government held to a pro-growth line points to a strong degree of coherence within the Irish Flexible Developmental State. Nonetheless, in theorizing the political ecology of Tiger economies in the future, it will be instructive to build upon O'Rain's (2000) attempts to trace out the multiple forms of state apparatus that might fall within the umbrella of the developmental state tag, and in particular to tease out the conflicting agendas of different branches of the state involved in the governance of the environment.

\section{Scalar 'fixes' in the political ecology of Tiger}

states

Given the central importance of scalar 'fixes' in the Irish case study, it is useful to end with four key points concerning 'scale' that might serve to orient future work on the political ecology of Tiger states more generally. Although abstracted from the case study presented above, these points are entirely consistent with Brenner's (2001) recent proposition of a research agenda for work on the theory of scale more generally:

1. The 'scaling' of environmental governance (at supra-national, national, regional or local levels) makes a material difference to the kinds of transformations of nature that occur inside the developmental state. In 'scaling' solutions to ecological problems in certain ways, and institutionalizing remedial measures accordingly, Tiger states can promote certain kinds of interventions and foreclose others. The scaling of environmental governance has the power to generate different ecological outcomes and as such must be approached as an 'active progenitor of social processes' (Smith 1993, 101).

2. Given that 'scale' is imbued with causal properties, the key question then to emerge is who has the power to define the scalar scaffold against which solutions to ecological problems are framed. Key to answering this question must be an investigation of the power of the developmental state to junk, rejig, recalibrate, modify, and transform the existing scale division of the state in defence of the chosen accumulation strategy. The threats posed by transformed nature to the ongoing regime of accumulation results in a hierarchization and rehierarchization of the state and the environment emerges as an important force in the political structuration of the state apparatus.

3. Whilst scalar strategies are inevitably conceived to defend the chosen accumulation strategy, they also set the tapestry upon which resistance to this strategy works itself through. To this end, certain scalar solutions might facilitate particular forms of resistance whilst diminishing the potency of others. In so far as the threat posed by socio-nature is cultural rather than literal, scalar strategies must be approached as also being related dialectically to the nature and potency of 'culture wars' over transformed nature.

4. Whilst social struggles may focus upon the outcomes of particular scalar strategies (in the form of a cultural politics of transformed nature), scale itself can emerge as the 'object' of struggle. In recognizing that certain scalar strategies privilege some agendas above others, resistance movements who are keen on radically altering 
the kinds of transformations of nature that occur in developmental states may target the scalar strategy adopted itself. The governance of environmental scaling (who has the power to decide the 'scalar' constitution of ecological problems) then becomes a site of conflict in itself.

\section{Acknowledgements}

The author would like to acknowledge the assistance of the Carnegie Trust for Scotland for financial support to undertake fieldwork associated with this research in Ireland in January 2001. Thanks are also expressed to Sharon Galleitch for cartographic assistance. Finally, acknowledgements are due to Guy Baeten and the two referees who provided valuable comments on an earlier draft of the paper.

\section{Notes}

1 The Irish Times and Irish Independent are leading daily newspapers and publish same day editions on the WWW (www.ireland.com/ and www.unison.ie/ irish_independent/). A range of local and regional newspapers are also published on the WWW (www.niceone.com/newspap.htm).

2 Full transcriptions of Dáil and Seanad debates, Minutes from Parliamentary Committees and details of press releases from the Taoiseach's Office are published on the official Irish Government WWW page (www.irlgov.ie).

3 Interviews were conducted in January 2001 with the section in charge of waste management in the Department of Environment and Local Government (Dublin), the national environmental statistics office ENFO (Dublin), the Environmental Protection Agency (Waterford), the national environmental protest group VOICE (Dublin), the head of waste management in Dublin Corporation (Dublin), and local protest group, Galway for a Safe Environment (Galway). A field visit to the Kill landfill site, Arthurstown, was also undertaken in November 2001. This landfill is one of the most technologically sophisticated sites in Ireland and one of three landfill sites that takes waste from the Dublin conurbation.

4 Readers will note that the phrases 'thermal treatment', 'waste to energy' and 'incineration' are used throughout the paper. Of course, incineration is only one type of thermal treatment and one form of waste to energy. In the course of debate, the status of the term incinerator became a matter of dispute between officials, who insisted upon using the more general terminology, and local opposition groups, who claimed that failure to use the term incineration amounted to a political tactic designed to mislead the public. In this paper then, the phrases thermal treatment and waste to energy will be employed when talking about official documents, whilst the term incineration will be employed when the language of opposition groups is examined.

5 It should be noted that responsibility for the preparation of a waste management plan for hazardous waste was retained at the national level and allocated to the Environmental Protection Agency (1999). Given the small amounts of hazardous waste Ireland deals with, only through a national strategy might economies of scale be realized. Moreover, whilst the remainder of this paper focuses upon the problems that have surrounded the formulation of 'nonhazardous' regional plans, it would be misleading not to refer to a number of national initiatives that have been pursued by the Minister of the Department of Environment and Local Government, Noel Dempsey (such as Integrated Pollution Control (IPC) Licensing, Repak Ltd and the Licensing of waste recovery/ transportation/disposal facilities). These initiatives certainly cannot be read as decisive interventions capable of shifting the structure of waste management in Ireland - only waste management plans could engineer changes of this magnitude. Moreover, many of the initiatives have met with only variable success and have failed to realize their full potential. In a limited way, nonetheless, they do point to an interest on behalf of the national government in at least drawing attention to options at the top of the waste management pyramid and in enforcing more stringent controls on existing methods of disposal.

6 'Ambitious targets set as regions move to solve waste crisis', The Irish Times, 10 January 2001.

7 See, for instance, Senator Brendan Ryan's (Labour) contribution in Seanad Debates, 28 March 2001.

8 See, for instance, Seanad Debates, 3 February 1999; Dáil Debates, 1 June 1999; Dáil Debates, 26 October 2000; and Seanad Debates, 28 March 2001.

9 See, for example, Patricia Redlich's article in the Irish Sunday Independent on 11 June 2000 entitled, 'Communities around Ireland fighting a state-financed assault on our environment'.

10 Emer O'Kelly, Irish Sunday Independent, 31 December 2000.

11 See, for example, Frank O'Donald's article in The Irish Times on 6 March 2000 entitled, 'A filthy people laying waste to our environment'.

12 See, for example, Seanad Debates, 7 July 2000.

13 An investigation by the Health Research Board into the health effects of waste treatment facilities was finally announced in August 2001, but results will not be published until summer 2002 at the earliest - at which point all of the regional waste management plans should be adopted in any case. 
14 Remarkably, this legislation was tabled late on the evening of 18 April 2000 just before the Easter recess, and was passed through the Dáil on 19 April and Seanad on 20 April.

15 SIPTU is Ireland's largest national trade union movement and as such stands as the most powerful voice organized labour has in the country.

16 The Bill was introduced in full on 28 March 2001 to the Seanad by Fianna Fáil TD Noel Dempsey, Minister for the Environment and Local Government (Seanad Debates, 28 March 2001).

17 Senator Fergus O'Dowd, Fine Gael, Seanad Debates, 4 April 2001.

18 'Cork city to adopt waste plan despite local anger', The Irish Times, 31 July 2001.

\section{References}

Allen K 1999a The Celtic Tiger, inequality and social partnership Administration 47 31-55

- 1999b Immigration and the Celtic Tiger: a land of a thousand welcomes? in Dale $\mathbf{G}$ and Cole $\mathbf{M}$ eds The European Union and migrant labour Berg, Oxford 91-111

- 2000 The Celtic Tiger?: The myth of social partnership in Ireland Manchester University Press, Manchester

Bank of Ireland 2001 Quarterly Bulleting, Autumn 2001 Bank of Ireland, Dublin

Bello W and Rosenfield R 1990 Dragons in distress: Asia's miracle economies in crises Institute for Food and Development Policy, San Francisco

Benton T 2000 An ecological historical materialism in Gale F P and McGonigle R M eds Nature, production, power: towards an ecological political economy Elgar, Cheltenham 83-104

Boyle M 2000 Euro-regionalism and struggles over scales of governance: the politics of Ireland's regionalisation approach to Structural Fund allocations 2000-2006 Political Geography 19 737-69

Breathnach P 1998 Exploring the 'Celtic Tiger' phenomenon: causes and consequences of Ireland's economic miracle European Urban and Regional Studies 5 305-16

Brenner N 1998 Between fixity and motion: accumulation, territorial organisation, and the historical geography of spatial scales Environment and Planning D Society and Space 16 459-81

- 2001 The limits to scale? Methodological reflections on scalar structuration Progress in Human Geography 25 591-614

Castree N 1995 The nature of produced nature: materiality and knowledge construction in marxism Antipode 27 12-48

Cox K 1998 Spaces of dependence, spaces of engagement and the politics of scale, or: looking for local politics Political Geography 17 1-23

Coyle C and Sinnott R 1992 Regional elites, regional 'powerlessness' and European regional policy in Ireland Regional Politics and Policy 2 71-108
Crotty W and Schmitt D E 1998 Ireland and the politics of change Longman, London

Davoudi S 2000 Planning for waste management: changing discourses and institutional relationships Progress in Planning 53 165-216

Department of Environment and Local Government 1998a An overview of the waste management Act, 1996 Department of Environment and Local Government, Dublin

- 1998b Waste management: changing our ways Department of Environment and Local Government, Dublin

- 2000 Annual report, 1999 Department of Environment and Local Government, Dublin

Dunford N and Smith A 2000 Catching up or falling behind? Economic performance and regional trajectories in the 'new Europe' Economic Geography 76 169-95

Environmental Protection Agency 1999 Proposed national hazardous waste management plan Environmental Protection Agency, Wexford

— 2000a Ireland's environment: a millennium report Environmental Protection Agency, Wexford

-2000b National waste database report, 1998 Environmental Protection Agency, Wexford

European Commission 2001 Our future: our choice Office for Official Publications of the European Communities, Luxembourg

European Environment Agency 2000 Environment in the European Union at the turn of the century European Environment Agency, Brussels

Evans P 1995 Embedded autonomy: states and industrial transformation Princeton University Press, Princeton

Gandy M 1999 The Paris sewers and the rationalisation of urban space Transactions of the Institute of British Geographers 24 23-44

Hardoy J E, Mitlin D and Satterwaite D 1992 Environmental problems in Third World cities Oxford University Press, London

Harvey D 1996 Justice, nature, and the geography of difference Blackwell, Oxford

IBEC 2000 The need for a new approach; waste management in the twenty first century IBEC, Dublin

International Monetary Fund 2001 Country reports, Ireland 2001 (report no. 01/139) International Monetary Fund, Washington DC

Irish Government 2000 National Development Plan 20002006 Irish Government, Dublin

Kaika M and Swyngedouw E 2000 Fetishizing the modern city: the phantasmagoria of urban technological networks International Journal of Urban and Regional Research 24 120-38

Kim E M 1998 The four Asian Tigers: economic development and the global political economy Academic Press, San Diego

Labour Party 2001 Waste matters: Labour's alternative strategy for waste management Labour Party, Dublin 
Laffan B 1996 Ireland: a region without regions - the odd man out in Hooghe $\mathbf{L}$ ed Cohesion policy and European integration: building multi-level governance Oxford University Press, Oxford 320-37

Latour B 1993 We have never been modern Harvester Wheatsheaf, London

Leonard H J 1988 Pollution and the struggle for the world product: multi-national corporations, environment, and international competitive advantage Cambridge University Press, Cambridge

Low N and Gleeson B 1998 Justice, society and nature: an exploration of political ecology Routledge, London

Macleod G and Goodwin M 1999 Restructuring an urban and regional political economy: on the state, politics, scale and explanation Political Geography 18 697-730

MacSharry R and White P 2000 The making of the Celtic Tiger: the inside story of Ireland's boom economy Mercier Press, Dublin

Mallet V 2000 The trouble with Tigers Harper Collins, London

Memery C 2001 The housing system and the Celtic Tiger: the state response to a housing crisis of affordability and access European Journal of Housing Policy 1 79-194

Midland Health Board 2000 Public health and waste disposal in landfill sites and by incineration Midland Health Board, Tullamore

Murphy A E 2000 The Celtic Tiger: an analysis of Ireland's economic growth performance EUI working paper RSC no. 2000/16 Badia Fiesolana, San Domenico (FI)

O'Connor J 1988 Capitalism, nature, socialism: a theoretical introduction Capitalism, Nature, Socialism 1 11-38

OECD 1999 Environmental data OECD, Paris

- 2000 Environmental performance reviews: Ireland OECD, Paris

- 2001a The OECD environmental outlook OECD, Paris

- 2001b OECD economic outlook 70 OECD, Paris

O'Hearn D 1998 Inside the Celtic Tiger: the Irish economy and the Asian model Pluto Press, London

- 2000 Globalisation, 'new tigers', and the end of the developmental state? The case of the Celtic Tiger Politics and Society 28 67-92

O'Leary E 2001 Regional divergence in the Celtic Tiger: the policy dilemma Irish Banking Review Spring 2001
O'Rain S O 2000 The flexible developmental state: globalisation, information technology, and the 'Celtic Tiger' Politics and Society 28 157-94

Reardon-Anderson J 1997 Pollution, politics, and foreign investment in Taiwan: the Lukang rebellion Sharpe, London

Reaves E and Barrow M 2000 The impact of contracting out on the cost of refuse collection services: the case of Ireland Economic and Social Review 31 129-50

Rudden P J 2000 Changing our ways The Engineers Journal May 2000

Smith N 1984 Uneven development: nature, capital and the production of space Blackwell, Oxford

- 1992 Geography, difference, and the politics of scale in Doherty J, Graham E and Malek M eds Postmodernism and the social sciences St Martin's Press, New York 57-79

— 1993 Homeless/global: scaling places in Bird J, Curtis B, Putnam T, Roberston G and Tickner L eds Mapping the futures, local cultures, global change Springer Verlag, Berlin 59-74

Strasser S 2000 Waste and want: a social history of trash Owl books, New York

Sweeney P 1999 The Celtic Tiger: Ireland's continuing economic miracle 2nd edn Oak Tree Press, Dublin

Swyngedouw E 1996 The city as a hybrid - on nature, society, and cyborg urbanisation Capitalism, Nature, Socialism 71 65-80

- 1997 Neither global nor local; 'glocalisation' and the politics of scale in Cox $\mathbf{K}$ ed Spaces of globalisation Guilford Press, London 133-66

- 1999 Modernity and hybridity: nature, regeneracionismo, and the production of the Spanish waterscape, 1890-1930 Annals of the Association of American Geographers 89 443-65

- 2000 Authoritarian governance, power, and the politics of rescaling Environment and Planning D 18 63-76

Tallon F 2000 Ask not for whom the Tiger roars Oak Tree Press, Dublin

Tansey P 1998 Ireland at work: economic growth and the labour market, 1987-1997 Oak Tree Press, Dublin

Taylor G 1998 Conserving the Emerald Tiger: the politics of environmental regulation in Ireland Environmental Politics 7 53-74

Turner R K, Salmons R, Powell J and Craighill A 1998 Green taxes, waste management and political economy Journal of Environmental Management 53 121-36 